Jiří HAVLÍČEK ${ }^{1}$, Karel MYŠKA ${ }^{2}$, Waldemar TEJCHMAN ${ }^{3}$, Natálie KARÁSKOVÁ ${ }^{1}$ Rafael DOLEŽAL ${ }^{1}$, Nadezhda V. MALTSEVSKAYA ${ }^{4}$ and Karel KOLÁR ${ }^{1 *}$

\title{
MICROWAVE SYNTHESIS OF SULFANILIC ACID
}

\author{
SYNTEZA MIKROFALOWA KWASU SULFANILOWEGO
}

\begin{abstract}
Sulfanilic acid represents an important substance, which is frequently utilized in the industry of azo dyes as well as in drug development of antimicrobials (e.g. of sulfonamides). Students can also meet with such type of compounds in chemistry labs, for example, when they estimate $\mathrm{pH}$ by methyl orange indicator or prepare Orange II for textile colouring. Both of these dyes are products of azo coupling of sulfanilic acid as diazonium salt with $N, N$-dimethylaniline or 2-naphthol, respectively. In the article, we focus on the synthesis of sulfanilic acid as a well-known experiment in the organic chemistry education. The synthesis was modified as the solvent free and microwave assisted experiment under semimicroscale conditions. That experiment is very convenient for the organic chemistry courses in the university or the high school teaching.
\end{abstract}

Keywords: synthesis of sulfanilic acid, microwave assisted synthesis, solvent-free synthesis, school experiment, organic chemistry education

\section{Introduction}

Sulfanilic acid, of systematic name 4-aminobenzenesulfonic acid, is one of the most important organic compounds in chemistry and technology of azo dyes [1]. By reaction with an alkali nitrite in acid medium, sulfanilic acid provides diazonium salt that can easily couple as an electrophile with phenol in the alkaline medium or with aromatic amine in the acidic medium to form azo compounds. Many of these substances are used in practice as synthetic azo dyes in textile and food industry. The two well known dyes produced from sulfanilic acid are the acid-base indicator methyl orange and Orange II for textile colouring.

Synthesis of sulfanilic acid as a basic laboratory exercise is frequently involved in teaching chemistry at the university, but also at secondary school [2,3]. Preparation of sulfanilic acid as a school chemical experiment has been introduced, for instance, at the teacher training college [4-6]. The synthesis is based on sulfonation of aniline with concentrated sulfuric acid (Fig. 1). There are several didactical reasons for including the preparation of sulfanilic acid in the laboratory exercises. As already mentioned, it is

\footnotetext{
${ }^{1}$ Department of Chemistry, Faculty of Natural Sciences, University of Hradec Kralove, Hradec Králové, Czech Republic

${ }^{2}$ Institute of Social Work, University of Hradec Kralove, Hradec Králové, Czech Republic

${ }^{3}$ Department of Chemistry, Institute of Biology, Pedagogical University of Kraków, Krakow, Poland

${ }^{4}$ State Budget Institute of Professional Education, Moscow, Russia

*Corresponding author: karel.kolar@uhk.cz
} 
a significant intermediate of the dye synthesis which can be prepared from commercially available starting materials (aniline, concentrated sulfuric acid). Further, it is an illustrative example of electrophilic aromatic substitution associated with an interesting reaction mechanism (rearrangement of the intermediate - phenylsulfamic acid to sulfanilic acid). Finally, the product - sulfanilic acid exists in the form of internal salt which is a result of interactions between the acidic groups $\left(-\mathrm{SO}_{3} \mathrm{H}\right)$ and basic groups $\left(-\mathrm{NH}_{2}\right)$ present in the molecules.<smiles>Nc1ccccc1</smiles><smiles>COS(=O)(=O)O</smiles><smiles>N[S+](=O)(O)c1ccccc1</smiles><smiles>O=S(=O)(O)Nc1ccccc1</smiles><smiles>Nc1ccc(S(=O)(=O)O)cc1</smiles><smiles>[NH3+]c1ccc(S(=O)(=O)[O-])cc1</smiles>

Fig. 1. Synthesis of sulfanilic acid

However, the common method of the synthesis of sulfanilic acid used in the organic chemistry laboratory course has a drawback. According to the traditional procedure, mixture of aniline with concentrated sulfuric acid is refluxed for $4-5$ hours at $180-190^{\circ} \mathrm{C}$. This fact represents a disadvantageous feature in terms of the teaching management. It was therefore proposed to develop such a procedure that greatly accelerates the reaction. In this respect, microwave heating of the reaction mixture seems to bring about important practical benefits for organic chemistry teaching in general $[5,7]$. For this purpose, we investigated applicability of commercial microwave oven [8]. The preparation of sulfanilic acid was subsequently monitored by thin layer chromatography (TLC). Importantly, the reaction in the presence of microwaves can be implemented in a few minutes. Since the synthesis is carried out as a microscale experiment, we managed to save time, energy and material. On the other hand, traditional synthetic procedure is inconsistent with certain principles of Green Chemistry [9], such as long reaction time and large energy consumption.

\section{Experimental}

In accordance with the principles of Green Chemistry, the synthesis of sulfanilic acid was carried out as reaction of aniline with concentrated sulfuric acid without solvent in the presence of microwaves. This reaction was performed in commercial microwave oven $(2450 \mathrm{MHz}, 700 \mathrm{~W})$ - Figure 2. The reaction product was analyzed by thin layer chromatography (thin layer - Silica Gel, eluent: propan-1-ol : ammonia 2:1 (v/v), detection-UV / $\lambda=254 \mathrm{~nm}$ ). Thin layer chromatography was repeated also on cellulose (identification the isomers of sulfanilic acid). Under these circumstances, there is a significant shortening of the reaction time of the original procedure (about several hours) to a few minutes, saving the energy required to heat the reaction mixture. 


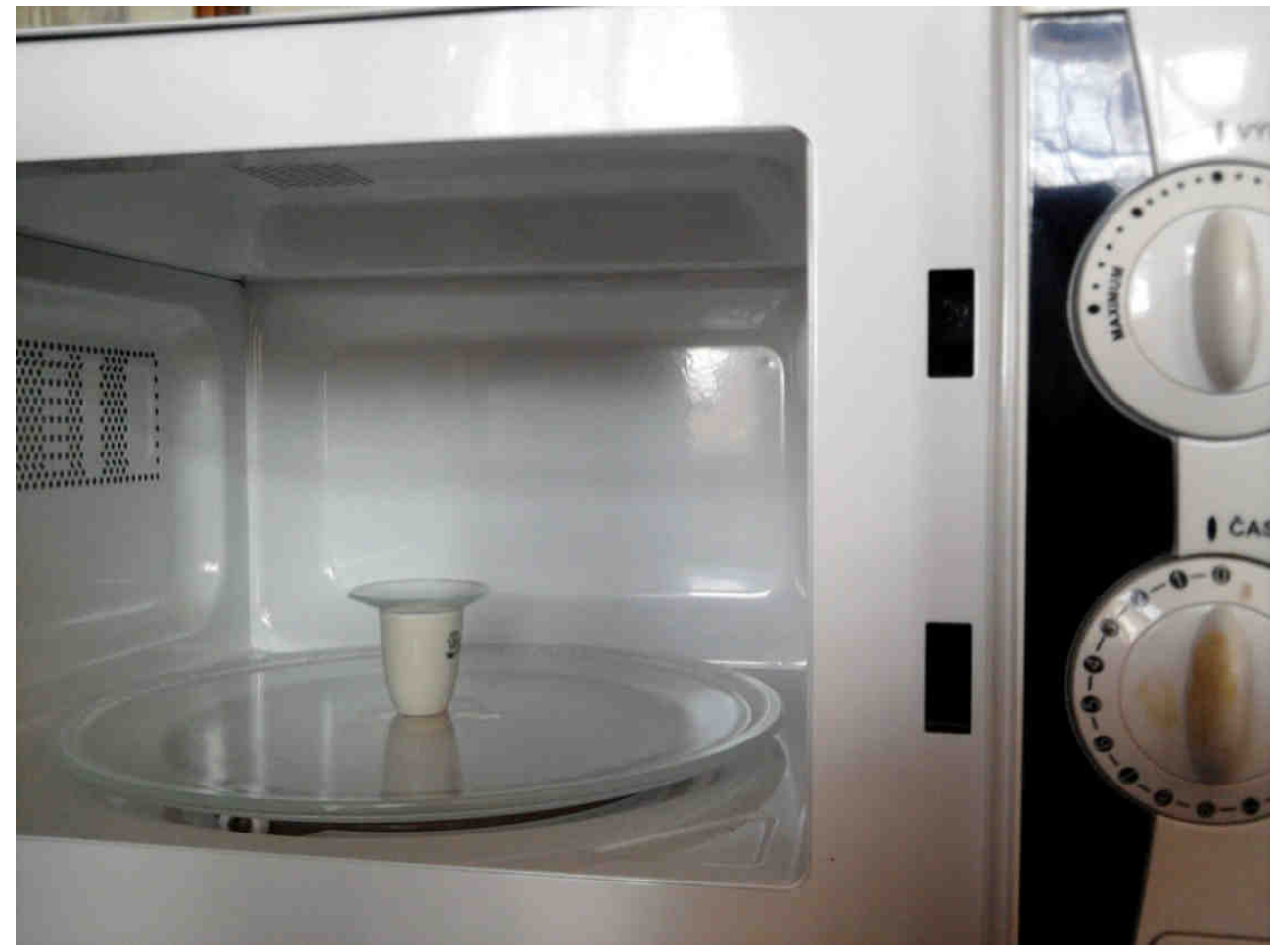

Fig. 2. Solvent-free synthesis of sulfanilic acid in microwave oven

\section{Procedure of the experiment:}

1) Weigh $0.10 \mathrm{~g}$ of aniline and add $0.20 \mathrm{~g}$ concentrated sulfuric acid into porcelain cup $\left(10 \mathrm{~cm}^{3}\right)$.

2) Cover the crucible with a watch glass and place it in the center of the rotating plate in microwave oven.

3) Heat the reaction mixture at half of the microwave power (i.e. $350 \mathrm{~W}$ ) for 2, 3, 4 min (half output).

4) After heating the crucible with the reaction mixture, place it for about $5 \mathrm{~min}$ in the ice-box.

5) From the reaction mixture in the crucible, take a small sample (using spatula tip) to a test-tube and dissolve it in the mixture of propan-1-ol and ammonia 2:1 (v/v) (about $\left.3 \mathrm{~cm}^{3}\right)$.

6) In the second test-tube, dissolve a drop of aniline (standard) in about $3 \mathrm{~cm}^{3}$ of the same solvent mixture as above, in the third test-tube, dissolve a small amount (spatula tip) sulfanilic acid as a standard, in about $3 \mathrm{~cm}^{3}$ of the same solvent mixture.

7) Drop a sample of the reaction mixture together with the samples of both standards to thin layer with the luminescent indicator and place into the chromatography chamber with the eluent.

8) Take the chromatogram out of the chamber, let it freely dry, and detect the compounds under UV lamp $(\lambda=254 \mathrm{~nm})$. 


\section{Results and discussion}

Aniline and sulfanilic acid form dark spots on TLC plate (aniline $-R_{F}=0.91$, sulfanilic acid $-R_{F}=0.57$ ). In the reaction mixture, sulfanilic acid was identified as the main product. In some cases, the presence of by-products and unreacted aniline were also confirmed. In the reaction mixture, no isomers of sulfanilic acid were detected. As can be seen in Figure 3, sulfanilic acid is produced in significant amount after 2 minutes of microwave irradiation and prolonging the reaction time over 3 minutes leads to formation of several by-products. Since the by-products have generally lower retardation factors than sulfanilic acid, we can suppose that the reaction goes on towards production of polarized compounds with great molecular weight such as quinoneimine dyes. For example, the quinoneimine dyes based on the induline structure can be the by-products of the reaction (Fig. 3 - reaction mixture E, Fig. 4 - Induline 3B as one of type quinoneimine dyes).

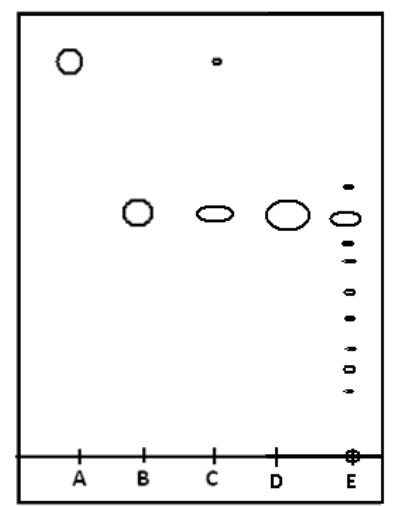

$$
\begin{gathered}
\text { A - aniline } \\
\text { B - sulfanilic acid } \\
\text { C - reaction mixture (time of heating - } 2 \mathrm{~min} \text { ) } \\
\text { D - reaction mixture (time of heating - } 3 \mathrm{~min} \text { ) } \\
\text { E - reaction mixture (time of heating - } 4 \mathrm{~min} \text { ) }
\end{gathered}
$$

Fig. 3. Synthesis of sulfanilic acid - TLC analysis of the reaction mixture<smiles>Nc1ccc2nc3cc(Nc4ccccc4)c(Nc4ccccc4)cc3[n+](-c3ccccc3)c2c1</smiles>

Fig. 4. Induline 3B - type of quinoneimine dye

Synthesis of sulfanilic acid is also interesting in terms of microwave heating conditions. This requires the presence of polar substances in the reaction mixture. The formation of anilinium hydrogen sulfate as a polar substance at the beginning of the reaction is a positive factor for microwave heating. The final product - sulfanilic acid is found in the form of internal salt (dipolar ion), which is also a polar substance. In this case, 
however, this is a negative circumstance. Intensive and long heating of the internal salt leads to the formation of a mixture of quinoneimine dyes. Therefore, for the synthesis of sulfanilic acid, reaction conditions must be chosen to minimize the formation of these by-products. Further intensive heating of sulfanilic acid is not desirable in terms of quantity and quality of the main product.

From these results, students can easily understand that microwave irradiation supports the reaction rate of the synthesis of sulfanilic acid. Along with increasing the selectivity of reactions, accelerating the reaction processes belongs to the main principles of Green Chemistry. In general, microwave radiation can be absorbed by polar molecules exhibiting dipole moment like water and converted into thermal molecular movement. In comparison with conventional heating, microwave irradiation causes local superheating and may elicit also special non-thermal effects, which have great impact on numerous chemical reactions. Thus, it has become evident that using household microwave oven it is possible to obtain many interesting outcomes, which highlights the benefits of microwave-supported synthesis.

\section{Conclusions}

The synthesis of sulfanilic acid can be readily accomplished in micro or semimicro scale as a solvent-free microwave assisted reaction. Under these conditions, the experiment conforms to the principles of Green Chemistry taking into account ecological and economic criteria. Due to the above requirements and also the simplicity of this experiment, the proposed microwave supported synthesis of sulfanilic acid is suitable for use in teaching chemistry at the university and the high school.

\section{References}

[1] Bourne RJ, Kurt MK, Lenzner J, Maire H. Ind Eng Chem Res. 1990;29:1761-1765. DOI: 10.1021/ie00105a004.

[2] Young JA. J Chem Educ. 2006;83:990. DOI: 10.1021/ed083p990.

[3] Rens L, Dijk H, Mulder J, Nieuwland P. J Chem Educ. 2013;90:574-577. DOI: 10.10121/ed300719q.

[4] Afonso CA, Candeias NR, Simao DP, Trindade AF, Coelho JA, Tan B, Franzen R, editors. Comprehensive Organic Chemistry for the Laboratory Classroom. Cambridge: Royal Society of Chemistry; 2016.

[5] Loupy A. Microwaves in Organic Synthesis. New Jersey: Wiley-VCh Verlag GmbH Co; 2006.

[6] Roeges N. J Chem Educ. 1968;45:274. DOI: 10.1021/ed045p274.

[7] Montes I, Sanabria D, García M, Castro J, Fajardo J. J Chem Educ. 2006;83:628-631. DOI: 10.1021/ed083p628.

[8] Giguere RJ, Bray TL, Duncan SM, Majetich G. Tetrahedron Lett. 1986;27:4945-4948. DOI: 10.1016/S0040-4039(00)85103-5.

[9] Anastas PT, Warner JC. Principles of Green chemistry. In: Green Chemistry: Theory and Practice. New York: Oxford University Press; 1998. 


\title{
SYNTEZA MIKROFALOWA KWASU SULFANILOWEGO
}

\author{
${ }^{1}$ Katedra Chemii, Uniwersytet Hradec Kralove, Hradec Králové, Czechy \\ ${ }^{2}$ Instytut Pracy Socjalnej, Uniwersytet Hradec Kralove, Hradec Králové, Czechy \\ ${ }^{3}$ Katedra Chemii, Instytut Biologii, Uniwersytet Pedagogiczny w Krakowie, Kraków, Polska \\ ${ }^{4}$ Państwowy Instytut Edukacji Zawodowej, Moskwa, Rosja
}

\begin{abstract}
Abstrakt: Kwas sulfanilowy stanowi ważną substancję, często stosowaną w przemyśle barwników azowych, jak również w produkcji leków przeciwdrobnoustrojowych (np. sulfonamidów). Studenci mogą również spotykać się z takimi związkami w laboratoriach chemicznych, na przykład przy oznaczaniu $\mathrm{pH}$ z wykorzystaniem oranżu metylowego lub przy przygotowywaniu Oranżu II dla przemysłu tekstylnego. Oba te barwniki są produktami sprzężenia soli diazoniowych kwasu sulfanilowego odpowiednio z $N, N$-dimetyloaniliną lub 2-naftolem. W artykule przedstawiono syntezę kwasu sulfanilowego jako przykład dobrze znanego eksperymentu w edukacji chemii organicznej. Syntezę zmodyfikowano jako reakcję bez rozpuszczalników i wspomagano mikrofalowo w warunkach półmikropreparacji. Eksperyment ten powinien być przedstawiany podczas kursów chemii organicznej na uniwersytecie lub w szkole średniej.
\end{abstract}

Słowa kluczowe: synteza kwasu sulfanilowego, synteza mikrofalowa, synteza bez rozpuszczalnika, eksperyment szkolny, edukacja chemii organicznej 